\title{
CORRESPONDENCE
}

\section{Palynology and British Purbeck facies}

SIR - Palynostratigraphic observations made 20 years ago (Norris, unpub. Ph.D. thesis, Univ. Cambridge, 1963, p. 373, text-fig. 44) indicated that marine dinoflagellate assemblages from the uppermost Portland strata immediately beneath basal Purbeck Beds at the Mountfield Mine in Sussex correlated with the Black Sandstones and Parallel Bands of the Isle of Purbeck and the upper part of the West Weare Sandstones of the Isle of Portland (upper Glaucolithites glaucolithus Zone and lower Galbanites okusensis Zone). Spore-pollen assemblages from the basal part of the Mountfield Purbeck Beds in the southern Weald correlate with those in Dorset closely superjacent to the Cinder Bed in the Durlston section (Norris, 1969; Dörhöfer \& Norris, $1977 a, b)$. Thus a major hiatus is indicated in the Weald spanning the time during which the Portland Stone and most of the lower part of the Purbeck Limestone Formation were deposited in Dorset (Fig. 1). The nature and extent of this hiatus has been investigated recently by Wimbledon \& Hunt (1983) who further refined the palynostratigraphy of the marine and non-marine facies and suggested different correlations for part of the Purbeck facies. Their data together with ammonoid determinations in Cope et al. (1980, p. 92) and by others in earlier publications indicated that marine Portlandian facies do not occur in the Weald younger than kerberus Zone. In some areas of the southern Weald, marine facies are not younger than glaucolithus Zone (Norris, 1969; Wimbledon \& Hunt, 1983).

Wimbledon \& Hunt (1983) concur with Norris in suggesting that late Portlandian time is not represented in the areas of Mountfield and Brightling at the Sussex outcrop and present evidence to suggest that an interval of erosion preceded the onset of Purbeck facies sedimentation in the southern Weald. However, Cope et al. suggested (1980, p. 92 and in column PO 12, fig. 15) that Purbeck facies sedimentation followed without interruption the kerberus Zone in the Warlingham Borehole in the northern Weald. In other words, in their view the lower part of Purbeck Beds in the Warlingham Borehole correlates with the Titanites anguiformis Zone and Titanites oppressus Zone of Dorset, and is therefore partially coeval with deposition of the marine Portland Freestone of the latter area. No data supporting these correlations are provided by Cope $e t$ al. (1980).

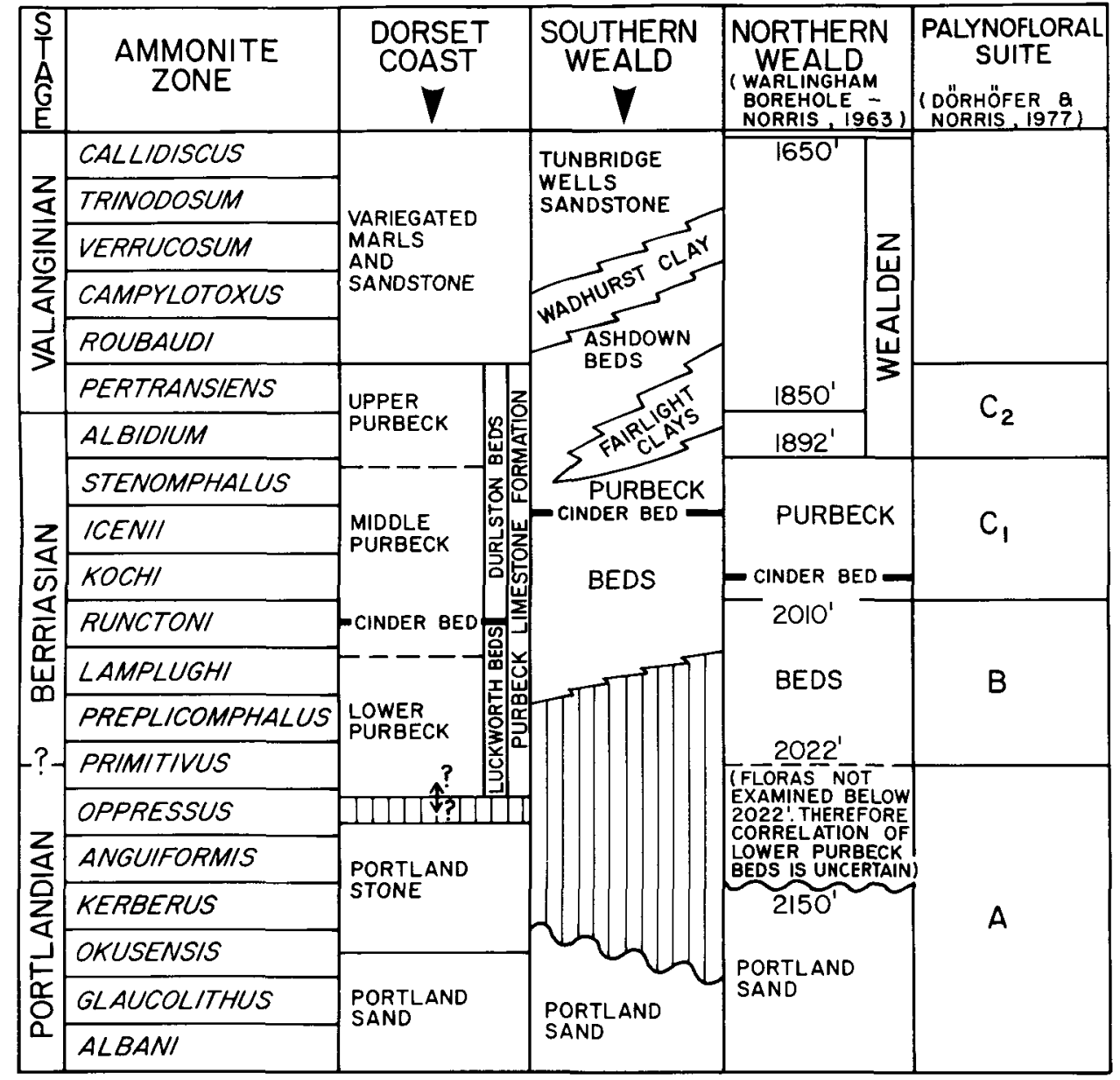

Figure 1. Palynostratigraphic correlation of strata near the Jurassic-Cretaceous boundary. The information in the northern Weald column is taken from Norris's unpublished Ph.D. thesis, University of Cambridge, 1963. Ammonite zones after Cope et al. (1980). See text for further explanation. 
In their commentary on Wimbledon \& Hunt's paper, Worssam \& Ivimey-Cook (1984) presented further alternative interpretations and correlations of the facies change from marine Portland strata to non-marine or brackishlagoonal Purbeck strata and indicated strong disagreements with some palynostratigraphic correlations. Essentially, the problem is this: is it possible to date the lowest Purbeck facies overlying the highest marine Portland strata in southern England? If this is possible, then the extent of the hiatus - if such exists - can be gauged or the diachroneity of the Purbeck facies - if such exists - can be recognized.

There would seem to be little doubt now that both Titanites zones of the late Portlandian (anguiformis and oppressus Zones) are absent in the Weald; possibly in some areas the kerberus Zone and okusenis Zone are also absent. In southern Dorset, the earliest Purbeck facies appear as a regressive phase conformably overlying the Titanites anguiformis Zone and the lower part of the Titanites oppressus Zone. Norris (unpub. Ph.D. thesis, Univ. Cambridge, 1963; 1969) and Dörhöfer \& Norris $(1977 a, b)$ have recognized several suites of spores and pollen from the latest Jurassic and earliest Cretaceous of northwest Europe. Similar assemblages with similar temporaral relationships are known from coeval strata north to paleolatitude $70^{\circ} \mathrm{N}$ in northern Canada (Fensome, 1983, and unpub. Ph.D. thesis, Univ. Saskatchewan, 1983) and westwards and southwestwards along the north shore of the early Atlantic Ocean through atlantic Canada to approximately $30^{\circ} \mathrm{N}$ in Maryland (Williams, 1975; Bebout, 1981; Doyle, 1983). This widespread distribution of spore-pollen floras clearly indicates their value for regional correlation. Their occurrence in latest Jurassic and earliest Cretaceous non-marine (Maryland), marginal marine mudflats (Dorset) and fully marine strata (eastern and northern Canada) further underlines their value for correlation across facies. The distinctive association of spore-pollen species in the lowest Purbeck facies of Mountfield and Brightling, southern Weald (Norris, 1969, Dörhöfer \& Norris, $1977 a, b$; Wimbledon \& Hunt, 1983) indicates a correlation of these gypsiferous horizons with non-evaporitic horizons below (Wimbledon \& Hunt, 1983) or just above (Norris, 1969) the Cinder Bed in Durlston Bay, Dorset.

Worssam \& Ivimey-Cook (1984) correctly state that Norris (1969) did not mention the semi-arid climatic conditions indicated by the Purbeck sedimentology, but they did not apparently use Norris's (1973) discussion of the climatic significance of spore-pollen floras associated with evaporitic Purbeck facies or Dörhöfer \& Norris's (1977b) discussion of variation in Purbeck aridity and its relationship to climatic zones and depositional environments. In both Dorset and Sussex, the gypsiferous sediments are marked by notably high proportions of Classopollis spp. due to the local dominance of conifers in the salt flats indicated by high tetrad counts in both localities, but of markedly different ages indicated by filicalean, lycopsid, and hepatic spores. In other words, floras adapted to a semi-arid climate or sabkha environments tend to dominate locally whereas the pteridophyte and bryophyte components of the flora continued to evolve (perhaps outside the saline areas) and provide sensitive biostratigraphic indices. Ephemeral freshening of the saline coastal lagoons and salt flats may have occurred in the Purbeck facies as today occurs in coastal areas of South Australia (West, 1975). Alternatively or additionally, longer term arid and non-arid cycles and resultant fluctuations in fresh water run-off may be related to precession of the equinoxes (Anderson \& Bazley (1971, pp. 23-33).

Worssam \& Ivimey-Cook appear to favour West's (1975) scenario of moving vegetation belts (warm-temperature to the north; arid to the south) which progressed southwards across southern England during the mid-Portlandian and early Berriasian to explain the distribution of evaporites and floras. They accept the concept of a single episode of aridity and therefore the near contemporaneity of Purbeck gypsum across southern England. Clearly such is not the case within the limited time interval of the Purbeck facies if one accepts the validity of the palynostratigraphic correlations. Palaeomagnetic data (e.g. Smith \& Briden, 1977) indicated no notable northward shift of northwest Europe between late Jurassic and late Cretaceous. Major changes of climate would therefore be related to changes in climatic gradient across latitude in this region caused by some other factors, e.g. uplift of the Anglo-Brabant Massif (Sladen \& Batten, 1984). In contrast to Worssam \& Ivimey-Cook's interpretation, a picture emerges, from palynostratigraphic considerations, of salt flats and flanking shallow marine environments in Dorset during deposition of the lower Purbeck giving way to less evaporitic environments periodically flooded by more normal shallow marine waters with locally abundant Liostrea banks in various Cinder Bed horizons. The southern Weald was probably emergent during most of this time and was undergoing (or had undergone) erosion. About the time of marine flooding of Dorset in Durlston Cinder Bed time, the southern Weald block became the site of evaporitic sedimentation. The northern Weald, as represented by Purbeck facies in the Warlingham Borehole, is closer chronostratigraphically to Dorset than the southern Weald. The Cinder Bed in the Warlingham Borehole may be slightly but not notably younger than the Cinder Bed in Dorset (Norris, 1969) and is associated in both areas with a decline in Classopollis spp. and associated tetrads concomitant with a rise in taxodiaceous pollen (Norris, unpub. Ph.D. thesis, Univ. Cambridge, 1963, pp. 341-4, text-fig. 34). In the southern Weald, Classopollis-producing plants locally dominated the gypsiferous sediments which commenced deposition slightly earlier than the main phase of marine flooding (possibly several transgressive events) which led to the local buildup of the Liostrea banks in both Dorset and the northern Weald.

Worssam \& Ivimey-Cook (1984) appeared to have some difficulty accepting the palynostratigraphic correlation of the Warlingham Cinder Bed with a horizon at the Sussex gypsum mines and in the southern Weald outcrop just above the Gypsiferous Beds. They emphasized the close lithostratigraphic match between the central Sussex outcrop and the somewhat thinner but similar development in the Warlingham Borehole $48 \mathrm{~km}$ to the northwest. In the ensuing discussion, they implied a correlation of all pre-Cinder Bed Purbeck strata across southern England, the onset of this facies development following a non-sequence consequent on early Portlandian movement. In their view, Purbeck sedimentation across southern England commenced at a mid-Portlandian, post-kerberus Zone date. This argument appears to be based solely on lithostratigraphy which is doomed by its very nature usually to yield inaccurate correlations except by chance. Nevertheless, their model does have the advantage of simplicity and yields a model for structural development of the Dorset-Sussex area essentially following the simple crustal downwarp model of Howitt (1964). Indeed, in southern Dorset a gradual 
thinning of Purbeck strata westwards from Durlston Bay to the basin margin can be demonstrated, the attenuation being apparently more or less evenly distributed across the Purbeck lithostratigraphic units (Norris, unpub. Ph.D. thesis, Univ. Cambridge, 1963; 1969). Simple downwarp, however, did not prevail in the Weald. Palynostratigraphic correlations indicate the existence of a tectonic high across the southern Weald clearly related to different patterns and temporal relationships of facies compared with Dorset to the west and Warlingham in the northern Weald to the northwest. The situation is further complicated by the existence of freshwater and brackish carbonate intervals in the Durlston Beds of south Dorset which near the top correlate with the onset of coarse clastic fluvial and interbedded argillaceous overbank and lacustrine muds of the lower Hastings Bed in Sussex. Examination of spore-pollen assemblages in the lowest Purbeck of the Warlingham Borehole will be crucial in clarifying tectonosedimentary relationships between the northern and southern parts of the Weald.

In spite of the shortcomings of their model adequately to take account of intra-Purbeck facies correlations, Worssam \& Ivimey-Cook (1984) raise an important point - how sure can we be that the Purbeck facies development in southern Dorset followed immediately upon cessation of marine deposition of the oppressus Zone of the Portland Freestone? Stratigraphers working in this area over the last century seem to have taken as a matter of faith that the Hard Cap of the basal Purbeck Limestone Formation was deposited immediately upon withdrawal of the Portland Freestone sea. In fact, virtually no evidence has been adduced to date for or against this assumption.

Wimbledon \& Hunt (1983) have pointed out that the Purbeck facies are characterized by scattered marine microfossils (as well as macro-invertebrates) and suggest that these might collectively help to resolve the JurassicCretaceous boundary position. Meanwhile, awaiting publication of Hunt's study of the Purbeck dinoflagellates, it is worth noting the following observation culled from Norris's thesis (unpub. Ph.D. thesis, Univ. Cambridge, 1963). A species attributed therein by Norris (p. 232, pl. 10, figs. 3-4; text-figs. $15 a, 16 a$ ) to Pseudoceratium and incorrectly by Dörhöfer \& Norris (1977b) to Necrobroomea gochtii (Alberti) Wiggins is clearly Batioladinium pomum Davey (1982, p. 21, pl. 5, figs. 1-4). B. pomum occurs at the base of palynofloral Suite B in a buff calcareous shale with ostracodes immediately above the Broken Beds at the base of the Marls with Gypsum and Insect Beds in the Durlston section, Dorset. This species ranges upwards at Duriston to the middle of the Corbula Beds in the lower part of palynofloral Suite C. Davey (1982) indicated that $B$. pomum enters near the top of the lower Berriasian occurring only in the lamplughi Zone in eastern England but ranging from the mid-Cannosphaeropsis thula dinoflagellate Zone (approximately top runctoni Zone) to near the top of the Pseudoceratium pelliferum dinoflagellate Zone (approximately top albidum Zone) in Denmark. If these ranges represent the total range zone of $B$. pomum, then clearly the Caps and Dirt Beds and Broken Beds at Durlston ante-date the lamplughi Zone and span (at least partially) the interval represented by the oppressus Zone, primitivus Zone and the preplicomphalus Zone, although a complete sedimentary representation is not necessarily indicated (see Fig. 1 which indicates this uncertainty). Further careful work on the dinoflagellates from this interval and comparisons with the
North Sea and offshore eastern North America may resolve the question as to whether a significant hiatus exists beneath the Purbeck facies in Dorset or not.

Wimbledon \& Hunt (1983) raise a further interesting possibility using palynostratigraphic arguments that the base of the Berriasian may be located well below the Cinder Bed, but not at the base of the Dorset Purbeck Limestone Formation as indicated by Dörhöfer \& Norris $(1977 a, b)$. If this can be refined further, it may be combined with the arguments presented in the preceding paragraph to gauge how much, if any, latest Portlandian time is unrepresented by sediments in southern Dorset. Meanwhile, attention is drawn to Fensome's (1983, and unpub. Ph.D. thesis, Univ. Saskatchewan, 1983) correlation of Purbeck Palynofloral Suite B with the lower part of his Cicatricosisporites purbeckensis Interval Zone. In northern Canada, the base of the latter zone is found in the top part of the Husky Formation containing pelecypods and other fauna assigned to the Buchia okensis Zone which Jeletzky (1973) correlates approximately with the early Berriasian Berriasella grandis Zone and part of the Berriasella boissieri Zone of southern Europe which in turn correlate with the primitivus Zone or preplicomphalus Zone of northwest Europe, and which - if correct - implies a correlation of the Durlston Cinder Bed (near the top of palynofioral suite B) and adjacent strata with the upper part of these lower Berriasian zones. Meanwhile, awaiting further detailed work on these correlations, the Dorset Cinder Bed in Figure 1 is correlated by convention with the runctoni Zone.

Finally, a major dispute remains to be resolved as to how much influence marine waters from the North Sea area played in saline deposition in the Purbeck facies in southern England (Wimbledon \& Hunt, 1983). Norris \& Jux (1984) have indicated by detailed structural analysis of walls of Portlandian dinoflagellate cysts that in the albani to early kerberus interval, a major hydrographic front may have been in existence in or near southern Dorset perhaps related to intrusion of cooler Boreal waters into the warmer Tethyan water mass occupying southern England. Of the species used in this analysis, one of them (Tityrosphaeridium porosispinum (Davey) Norris \& Jux) ranges upwards from Portlandian marine facies into the lower part of the Purbeck Limestone Formation a few metres below the lowest gypsiferous beds in the Durlston section (Norris, unpub. Ph.D. thesis, Univ. Cambridge, 1963). This species is represented by the strongly fibrous vesicular cysts characteristic of the Portlandian marine facies near the putative hydrographic front, not the smoother cysts characteristic of the North Sea. In the North Sea region, this species has a longer range up to approximately the stenomphalus Zone. The highly vesicular nature of the strongly textured cysts characteristic of the marine Portlandian is believed to be related to the mingling of warm and cooler waters (Norris \& Jux, 1984). If this is confirmed, then the presence of the fibrous vesicular cysts in the lower part of the Purbeck facies in Dorset would suggest a continuing mixing of Boreal and Tethyan waters. Much more detailed work is required to refine this approach.

Acknowledgements. This work was made possible by an operating grant from the Natural Sciences and Engineering Research Council of Canada. Dr R. A. Fensome provided valuable discussion and details of palynostratigraphy of northern Canada. 


\section{References}

Anderson, F. W. \& Bazley, R. A. B. 1971. The Purbeck Beds of the Weald (England). Geological Survey of Great Britain, Bulletin no. 34, 174pp.

Bebout, J. W. 1981. An informal palynologic zonation for the Cretaceous system of the United States mid-Atlantic (Baltimore Canyon area) outer continental shelf. Palynology 5, 159-94.

Cope, J. C. W., Duff, K. L., Parsons, C. F., Torrens, H. S., Wimbledon, W. A. \& Wright, J. K. 1980. A Correlation of Jurassic Rocks in the British Isles. Part Two: Middle and Upper Jurassic. Geological Society of London, Special Report no. 15, 109pp.

DAvEY, R. J. 1982. Dinocyst stratigraphy of the latest Jurassic to early Cretaceous of the Haldager No. 1 borehole, Denmark. Danmarks Geologisk Undersogelse, Ser. B (6), 1-57.

DÖRHÖFER, G. \& NoRRIS, G. $1977 a$. Palynostratigraphische Beitrage zur Korrelierung jurassisch-kretazischer Grenzschichten in Deutschland und England. Neues Jahrbuch für Geologie und Paläontologie Abhandlungen 153 (1), 50-69.

DÖRHÖFER, G. \& NORRIS, G. $1977 b$. Discrimination and correlation of highest Jurassic and lowest Cretaceous terrestrial palynoflorasin north-west Europe. Palynology 1, 79-93.

DoYle, J. A. 1983. Palynological evidence for a Berriasian age of basal Potomac Group sediments, Crisfield well, eastern Maryland. American Association of Stratigraphic Palynologists, 16th Annual Meeting, Program and Abstracts, p. 13.

Fensome, R. A. 1983. Miospore stratigraphy of JurassicCretaceous boundary strata. American Association of Stratigraphic Palynologists, 16th Annual Meeting, Program and Abstracts, p. 16.

HowITT, F. 1964. Stratigraphy and structure of the Purbeck inliers of Sussex (England). Quarterly Journal of the Geological Society of London 120, 77-113.

JELETZKY, A. 1973. Biochronology of the marine boreal latest Jurassic, Berriasian and Valanginian in Canada. In The Boreal Lower Cretaceous (ed. R. Casey and P. F. Rawson), pp. 41-80. Liverpool: Seel House Press.

Norris, G. 1969. Miospores from the Purbeck Beds and marine Upper Jurassic of southern England. Palaeontology 12 (4), 574-620.
Norris, G. 1973. Palynological criteria for recognition of the Jurassic-Cretaceous boundary in western Europe. Akademie Nauk SSSR, Sibir. Otdel., Inst. Geol. Geofiz. Proceedings of the 3rd International Palynological Conference on 'Palynology of the Mesophyte', pp. 97-100. Moscow: Nauka Press.

NoRRIS, G. \& JUX, U. 1984. Fine wall structure of selected Upper Jurassic gonyaulacystinean dinoflagellate cysts from southern England. Palaeontographic A Abteilung $B$ 190, 158-68.

Sladen, C. P. \& Batten, D. J. 1984. Source-area environments of Late Jurassic and Early Cretaceous sediments in southeast England. Proceedings of the Geologists' Association 95, 149-63.

Smith, A. G. \& Briden, J. C. 1977. Mesozoic and Cenozoic palaeo-continental Maps. Cambridge University Press.

WEST, I. M. 1975. Evaporites and associated sediments of the basal Purbeck Formation (Upper Jurassic) of Dorset. Proceedings of the Geologists' Association 86 (2), 205-25.

WiLliams, G. L. 1975. Dinoflagellate and spore stratigraphy of the Mesozoic-Cenozoic, offshore eastern Canada. Geological Survey of Canada, Paper 74-30, vol. 2, 107-61.

Wimbledon, W. A. \& Hunt, C. O. 1983. The PortlandPurbeck junction (Portlandian-Berriasian) in the Weald, and correlation of latest Jurassic-early Cretaceous rocks in southern England. Geological Magazine 120 (3), 267-80.

Worssam, B. C. \& Ivimey-CoOK, H. C. 1984. Comments on the paper 'The Portland-Purbeck junction (Portlandian- Berriasian) in the Weald, and the correlation of latest Jurassic-early Cretaceous rocks in southern England' by W. A. Wimbledon \& C. O. Hunt. Geological Magazine 121 (6), 651-2.

\section{G. NORRIS}

Department of Geology

University of Toronto

Toronto, Ontario

M5S 1A

Canada

\section{August 1984}

